\title{
Cactus Nurseries and Conservation in a Biosphere Reserve in Mexico
}

\author{
María T. Pulido* and Consuelo Cuevas-Cardona \\ Authors' address: Universidad Autónoma del Estado de Hidalgo. Instituto de Ciencias Básicas e Ingenierías. Centro de \\ Investigaciones Biológicas. Km 4.5 Carretera Pachuca-Tulancingo. Pachuca, Hidalgo, Código Postal 42184, México. \\ *Corresponding author: mtpulido@yahoo.com
}

Received: March 4, 2013

Volume: 4:96-104

Published: September 3, 2013

(C) 2013 Society of Ethnobiology

\begin{abstract}
Documenting how socio-ecosystem conservation knowledge and practice arise and are modified are issues of ethnobiological interest. In the Barranca de Metztitlán Biosphere Reserve (RBBM), plant nurseries, some of which were created as Environmental Management Units (UMAs), have been established to grow and conserve cacti. This paper describes these nurseries, their role in cactus conservation, and the benefits and limitations for the people managing them. The nurseries have helped decrease illegal traffic in cacti and have enabled ex situ conservation of 22 cacti species. Cactus management has changed from extraction to cultivation, as a result of the knowledge and actions of multiple actors. The main limitation is marketing, a recurring problem for non-timber forest products (NTFP). Greater coordination among stakeholders is recommended, such as involvement by non-governmental organizations to improve their probability of success, as well as learning from the experience of other cactus UMAs. Improving the market for cacti is an issue that needs an immediate solution; otherwise conservation efforts could relapse.
\end{abstract}

Keywords: NTFP, Metztitlán Canyon, cacti, traditional wisdom, UMAs

\section{Introduction}

An ethnobiological issue of current interest is that of documenting how knowledge and sustainable conservation practices arise, are maintained, and/or are modified (Turner and Berkes 2006), especially in rural and indigenous villages (Berkes and Turner 2006). An understanding of these issues is a key part of extending sustainable practices to new areas, bringing together stakeholders who can integrate comprehensive conservation actions into existing socio-ecosystems.

Many researchers have concluded that local knowledge is a key element for helping solve complex environmental problems (Bowler 2000; Funtowicz and Marchi 2003) because indigenous and peasant communities hold a profound fount of accumulated knowledge based on the experiences of people who have been in close relationships with nature for millenia (Berkes and Turner 2006; Boege 2010; Leff 2005; Toledo 2002). Only recently has the scientific community begun to understand the importance of ancestral wisdom and shared responsibility (Anta Fonseca et al. 2008; Berkes and Turner 2006).
The current conservation paradigm no longer views the ecosystem and human beings as separate, but rather acknowledges the fundamental role of humans in socio-ecosystem management and conservation. Socio-ecosystems are complex systems whose proper management requires participative multiscale schemes and whose basic goal is both conservation and development through multicentric decision making (Berkes 2003; Berkes and Turner 2006; Campbell and Vainio 2003). As a consequence, the concept of protected areas has changed over time. Once they were zones from which local residents were removed, supposedly to prevent environmental degradation, but now there are protected areas where the participation of the people who live there is considered of vital importance.

Including humans in natural protected areas has given rise to the Biosphere Reserve model promoted by UNESCO (UNESCO 2013). The purpose of this model is to enable sustainable development based on local community efforts in protected areas. In Mexico, current environmental law based on the Convention on Biological Diversity and other precedents provides for Biosphere Reserves as one of several types of 


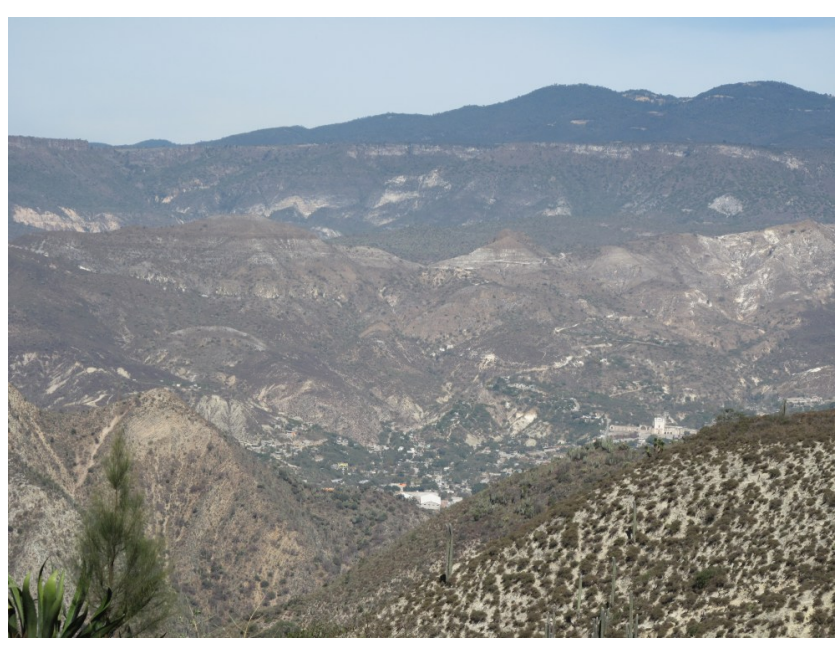

Figure 1. The Metztitlán Landscape. Xeric vegetation predominates in the mountains, while the Metztitlán town is located in the flat, with The Augustinian Ex Convento de los Santos Reyes, built in the XVI century, in the background.

natural protected areas (ANP for its name in Spanish) under federal jurisdiction.

In addition to ANPs, Mexico has Management Units for Wildlife Conservation (UMA in Spanish), that are currently the main legal instrument for achieving sustainable use of wild resources. These are legally constituted areas in which a management plan is carried out to conserve habitat and maintain wild populations for a variety of goals including sustainable use, teaching, and restoration. Widely accepted since they were first created in 1995, by 2008 they covered $15 \%$ of Mexico's land area, more than the total ANP land area in Mexico, resulting in a large potential impact on biodiversity conservation. Despite their importance in terms of land area, it is recognized that there must be more careful follow up of management plans and improved monitoring systems to obtain more detailed information about the impact of UMAs on the conservation of wildlife and nature (Anta Fonseca et al. 2008; Robles de Benito 2009).

Barranca de Metztitlán Biosphere Reserve (RBBM) is one of the ANPs in which UMAs have been established. It is a natural protected area rich in cactus species, especially endemic species, that was ransacked for a considerable period. The extracted plants were sold mainly in overseas markets. Scientists such as Helia Bravo (1978) began to draw attention to the uncontrolled removal of these plants. Residents began to organize, first to form squads of guards and eventually to lobby to have the biosphere reserve established (Cuevas-Cardona et al. 2008). The RBBM is a 2,090,512 hectare area created in November 2000 that includes parts of the municipios (county equivalents) of Acatlán, Atotonilco el Grande, Huasca, Eloxochitlán, Metztitlán, San Agustín Metzquititlán, and Zacualtipán in the state of Hidalgo. It includes arid tropical scrub, tropical deciduous forest, submontane scrub, pine forest, pasture, and riparian woodland ecosytems (CONANP 2003). The arid tropical scrub vegetation includes some sixty species of cactus, among which Echinocactus platyacanthus Link \& Otto Cactaceae, Cephalocereus senilis (Haw.) Pfeiff. Cactaceae, and Stenocereus marginatus (DC.) A. Berger \& Buxb. Cactaceae are notable.

In the RBBM, the federal agency in charge of conservation (CONANP) has supported plant nurseries as an example of an activity that both utilizes resources and promotes conservation. The underlying logic is that raising species that can be marketed as well as used for reforestation and/or restoration reduces the likelihood that these species will be plundered from their natural environment. However, this strategy must be analyzed in depth in the context of the framework of non-timber forest products (NTFP), such as these cacti. Recent comparative analysis on NTFP indicate that marketing is the key factor for their sustainable use, but also the most difficult to achieve (Marshall, Schreckenberg, and Newton 2006; Pulido et al. 2010). The most frequent error of many conservation and development projects in the past has been to conduct studies to ensure biologically sustainable production of the product while assuming unlimited market demand, which is often not the case; this has led to failure.

This paper analyzes the operation of several cactus nurseries in the RBBM in the context of how knowledge and conservation practices begin and are maintained or modified as a result of complex interactions between institutional, local, and external agents, and whether the cactus nursery is a sustainable alternative. The objectives of this study are to: a) analyze the emergence and organization of nurseries and their achievements and limitations in the opinions of their managers; b) document how conservation and knowledge practices have been generated; c) analyze the effect of the nurseries on cactus conservation, and evaluate whether nurseries have been able to decrease illicit removal of cacti. Using an ethnobiology approach, this case study seeks to contribute to the relationship between conservation and applied ethnobiology. 


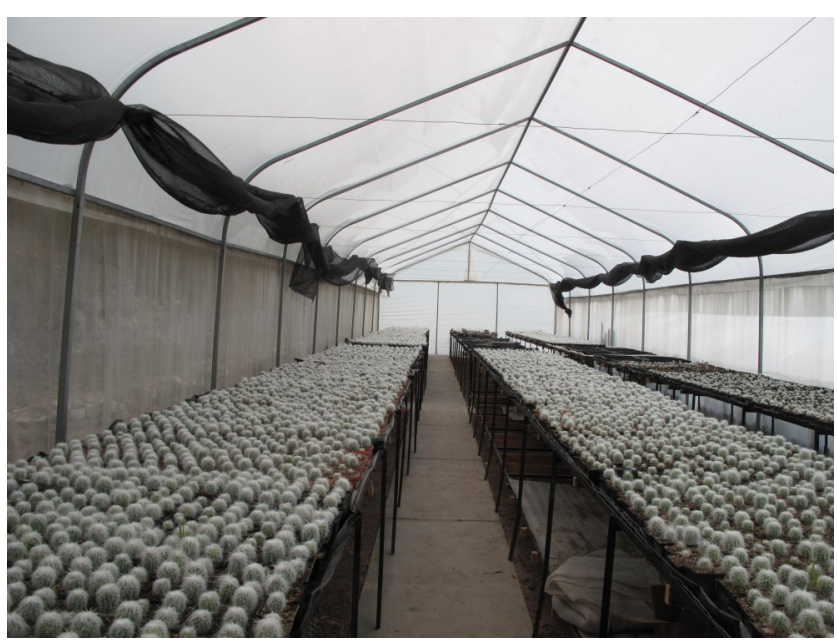

Figure 2. Hundreds of $C$. senilis propagated by seeds in El Viejo Cactus nursery.

\section{Methods}

In December, 2010, we visited the administrative offices of the reserve and interviewed two officials, asking them about the operation of the UMAs, the support they have received from the reserve, and their impact on cactus conservation in the region. They explained that three of the nurseries are registered UMAs (La Joya, Xochinanahual, and Acalometlán) and one is not. The four were included in this study to compare the responses given by people involved in cactus UMAs, and by people who ransacked cactus in the past. The four nurseries were visited in December 2010 and January 2011, and five semi-structured interviews with the managers were conducted. The interviews were one to two hours long, and each included a tour of the respective nursery.

The topics covered in each interview included: 1) origin of the nursery, changes in personnel and organization; 2) contribution of each person involved in generating and changing cactus conservation knowledge and practices; 3) cactus species; 4) achievements and limitations; 5) perception of the impact of the nursery on cactus extraction. The perceptions of local residents collected in the interviews were compared to identify patterns and, where possible, included in the comparisons to bibliographic data and official statistics.

\section{Results}

Emergence, Organization, Achievements and Limitations of the Cactus Nurseries

Biosphere reserve officials state that in 2002, the reserve began to promote the establishment of UMAs to produce cacti as a sustainable alternative to incorporating the area as an ANP. As a result, three UMAs were legally constituted, while several others, such as the San Cristobal nursery, have not yet been legally established.

At all three UMAs, the nursery managers reported support from the reserve administration to attend courses in production methods, cactus care and germination, and marketing. The administration also put them in touch with the National Forestry Commission (CONAFOR), which supports market research and courses in nationwide marketing. The following section describes the founding of the three UMAs and the San Cristobal nursery, and their achievements and limitations.

\section{La Joya}

La Joya nursery is managed by Mr. Baena (Figure 3), a farmer and construction worker by profession. The biosphere reserve officials invited him to organize the nursery and supported him in starting it. The eight people who started the nursery provided the labor while the reserve provided building materials and tools. However, six of the original participants lost interest because there were no immediate earnings or quick profit. Although this nursery is located in a remote village, they have sold plants to buyers from Xochimilco and Morelos. They met the buyers at one of the marketing courses organized by the reserve administration.

\section{Florycactus}

The Florycactus nursery (Figure 4) is part of the Xochinanahual UMA. It was started by two agricultural engineers, Acosta and Oaxaca. They invited people in their neighborhood of Tepeyac to start the nursery, and persuaded the community to donate the land for it. Mr. Oaxaca also designed the management plan. The group began with 50 people, mostly women, although in 2003 the nursery was legally constituted with 18 people. Currently there are only 12 members. Since committee work was not valued, they decided that each member would serve as administrator for one month. The members are now all trained to do all the jobs at the nursery. Their duties include working in the nursery two days a month and attending monthly meetings where the members analyze problems and consider new points of view.

The nursery was formed for the purpose of preserving the cacti. The income it generates does not support any of the members. All have other jobs: shopkeepers or construction workers, and several are 


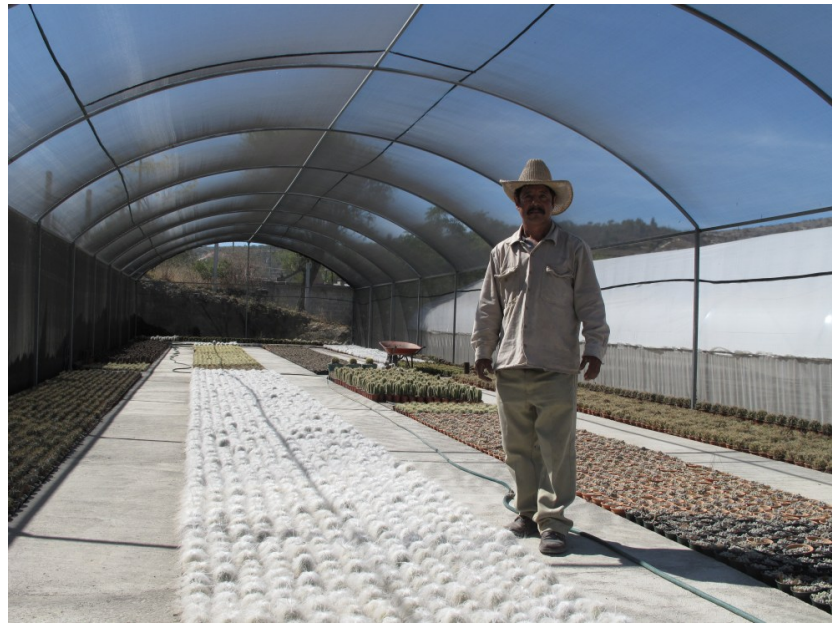

Figure 3. Mr. Baena in La Joya nursery with small Cephaloceros senilis propagated by seeds in front of him.

homemakers.

Their main challenge included buying a vehicle to take the plants to market. The main accomplishments include: a) good sales $(10,000$ to 22,000 pesos per month); b) attending trade fairs outside their region (the nursery workers have traveled to Mexico City, Uruapan, Guadalajara and Cuernavaca); c) carrying out environmental education; d) selling cacti for reforestation to other UMAs (including the distant Cuatrocienegas); e) serving as an example of organization for other UMAs; f) teaching cactus propagation to other UMAs; g) using profits to produce worm compost for cacti.

\section{El Viejo Cactus}

El Viejo Cactus (see Figure 2) is part of the UMA Acalometlán, it is managed by Valderrama and Sánchez. Sánchez had heard about the projects proposed by the management of the reserve, was interested in forming a UMA, and invited Valderrama, who was working in the United States at the time. It was started by six partners with four currently remaining. The families of two partners make a living from the nursery, although income from cactus sales is supplemented from the sale of flower pots (an innovative product they create from local materials) and two stores. The site has the advantage of being located by the side of the road, so it is seen by people traveling by.

The accomplishments of this UMA include: a) generating a source of local employment (reducing emigration); b) helping sell plants from other, more remote nurseries; c) environmental education for young people; d) conserving cacti. They state that creating the reserve and promoting nurseries has increased care for cacti and decreased extraction, which has helped natural regeneration. Limitations mentioned are that their website is very basic and they do not have a telephone number, which impedes their access to the non-local markets in the rest of Mexico.

\section{San Cristobal}

Three partners began the San Cristobal nursery of which two remain, but they closed it because it was not profitable. They were never incorporated as a UMA. They state that they receive much less support from the reserve than other nurseries. The plants are still there but receive only minimal care. The person who was in charge of the nursery, Mr. Flores, is now elderly and his sons need to do other work.

The Flores family spent several years selling wild cacti to foreigners. According to his sons, Mr. Flores was, "the most knowledgeable person about cacti in this region." They say that Japanese, Germans, and Americans came to Metztitlán with trucks to take away cacti. The brothers say that they did not only sell plants, but for a time they also sold seeds. In three months, four people working together managed to collect some 2 to 3 kilos of seed from wild cacti. The main achievements have been to teach bioreserve officials about cactus management, while the basic limitation has been the low level of sales.

From the officials' point of view, legal cactus sales are a good economic option, but the main limitation is the low level of business, made worse by the lack of organization and disputes between the managers. They consider that factors such as distrust between the managers have held the nursery back.

\section{Conservation Knowledge and Practices}

Various stakeholders have influenced the generation of knowledge and practices of cactus conservation at the local level. A key factor in improved practices has been the role of government institutions CONAFOR and CONANP (National Commission of Natural Protected Areas). Another key factor, as several managers stated, is their knowledge of cactus propagation, a combination of what they have learned at workshops, and their own daily experiments which they apply to improve their methods. Others mention exchanges of knowledge with UMA managers. The officials report that these training workshops were delivered by academic technicians from the National University of Mexico and state universities, although 
Table 1. Cactus seizures in Hidalgo of $E$. platyacanthus parts. PROFEPA 2013)*.

\begin{tabular}{llll}
\hline Year & $\begin{array}{l}\text { No. of } \\
\text { events }\end{array}$ & $\begin{array}{l}\text { No. of } \\
\text { plants }\end{array}$ & $\begin{array}{l}\text { No. of } \\
\text { species }\end{array}$ \\
\hline 2005 & 1 & 8 & 3 \\
2006 & 2 & 12 & 2 \\
2007 to 2010 & 0 & 0 & 0 \\
2011 & 2 & 4 & 2 \\
2012 & 4 & $96 *$ & 1 \\
\hline
\end{tabular}

these academics have played only a small role.

According to the Flores brothers (San Cristobal nursery), their father taught the bioreserve officials about cactus management, including the right way to harvest seed from wild cacti-the right time to extract them, how to determine the viability of the seed, and the common names of the local cacti. The Flores brothers would camp in the hills and they were able to extract quite large cacti, up to a meter and a half. They were able to do this, they said, because they knew the area and the plants well. When asked if they were concerned at the time that harvesting would finish off the cacti in the region, they said no, that they rotated their harvesting between different areas so that the populations would recover. They add that the more the plants are harvested, the more they produce, and it does them good to have their seed removed. Unfortunately, there are no scientific papers available to confirm this.

The Flores brothers stated that they taught the biosphere reserve administrators the techniques for harvesting the seeds of the C. senilis, since these are difficult to obtain. They told them how and where to get the seeds, when it is best to extract them, how to tell whether they are healthy or not and which ones should be planted. They estimate that a $C$. senilis that generates 30 fruits produces 3000 seeds, 100 per fruit. They need specific amounts of moisture and heat to germinate. The type of soil is also important; it must be white or brown, never black. The Flores brothers explained that these plants "face" north and that their reproductive structures are always formed on that side. Interestingly, Vazquez, Terrazas, Arias (2007) reported that the cephalium (the structure that gives rise to the fruit) is always on the north side.
Effects of Nurseries on Cactus Conservation and Decrease in Uncontrolled Extraction

Everyone involved agrees that they have benefited from the existence of the biosphere reserve, because they have been able to conserve cacti, while also creating a source of income. Previously, whole areas were stripped of plants. Japanese buyers, they say, came to extract them by the truckload and local people helped them only as day laborers. Since there is now a biosphere reserve, the people are more aware and the cactus populations have been regenerated. Robbins (2003) suggests that Japan and the United States have been the most frequent destinations for illegal export where the volume extracted is only a small part of what it was in the 1980s.

Like the nursery managers, the bioreserve managers consider that creating the reserve stopped much of the illegal extraction. At first, the biosphere managers formed squads to guard the area around the clock, to reduce the activity of the groups of cactus extractors. They halted the activity of some 15 to 20 groups of cactus extractors, and illegal extraction decreased by $80 \%$. They add that the local residents now understand that removing cacti is a federal offence and they report it. Official statistics from the environmental protection agency Procuraduría Federal de Protección al Ambiente (PROFEPA) show that nine cactus seizures have been reported in the last seven years, with a disturbing increase in 2012 (Table 1).

The positive impact on conservation is not only reflected in the reduction in uncontrolled extraction, but also in the role of the nurseries in cactus conservation, because they promote ex situ conservation of at least 22 species in 11 genera (Table 2). It is notable that six of the species grown by these nurseries are listed in the NOM-059-SEMARNAT-2010, which makes their conservation even more important. These six species are endemic to Mexico, so their conservation and propagation is one of the successes under the UMA scheme. There is also considerable ex situ conservation. Each nursery has permits to grow some 5,000 to 10,000 individuals of $C$. senilis.

A critical factor for conservation is the procurement of seeds used at the UMAs. The managers explain that the UMAs must prove that the seed they grow was acquired legally. Therefore, "mother plants" for generating seed are raised at all three UMAs. However, the seeds of C. senilis which is estimated to take 70 years to reach reproductive maturity, must be obtained by sustainable collection in the wild. There 
Table 2. Cactaceae species grown in Metztitlán nurseries, showing category of threatened species according to the Mexican NOM-059-SEMARNAT-2010.

\begin{tabular}{|c|c|c|c|}
\hline Genus \& Species & Species Authority & Spanish \& English Common Name & Category \\
\hline Astrophytum ornatum & (DC.) Weber ex Britt. Rose & liendrilla, star cactus & Threatened \\
\hline Cephalocereus senilis & (Haw.) Pfeiff. & viejito, old man cactus & Threatened \\
\hline Coryphantha octacantha & (DC.) Britton \& Rose & biznaga partida de ocho espinas & \\
\hline Echinocactus grusonii & Hildm. & biznaga dorada, golden ball & Endangered \\
\hline Echinocactus platyacanthus & Link \& Otto & biznaga gigante, giant barrel cactus & Protected \\
\hline Echinocereus cinerascens & Lem. & tuna de mayo & \\
\hline Ferocactus glaucescens & (DC.) Britton \& Rose & biznaga azul, blue barrel cactus & \\
\hline Ferocactus histrix & Lindsay & biznaga borrachita & Protected \\
\hline Ferocactus latispinus & (Haw.) Britton \& Rose & biznaga uña de gato, devil's tongue barrel & \\
\hline Mammillaria geminispina & Haw. & biznaga de chilitos, twin-spined cactus & \\
\hline Mammillaria gracilis & Pfeiff. & biznaga grácil, thimble cactus & \\
\hline Mammillaria magnimamma & Haw. & volcanes, Mexican pincushion & \\
\hline Mammillaria schiedeana & Ehrenb. ex Schltdl. & biznaga de Metztitlán & Threatened \\
\hline Mammillaria sempervivi & D.C. & biznaga siempre viva & \\
\hline Myrtillocactus geometrizans & (Mart. ex Pfeiff.) Console. & garambullo, blue candle & \\
\hline Neobuxbaumia polylopha & (DC.) Backeb. & órgano dorado, golden saguaro & \\
\hline Pachycereus weberi & $\begin{array}{l}\text { (J.M. Coult.) Backeb. } \\
\text { (A. Dietr.) A. Berger ex A.W. }\end{array}$ & órgano blanco, órgano webere & \\
\hline Stenocactus lamellosus & Hill & cactus estrella & \\
\hline Stenocereus dumortieri & (Scheidw.) Buxb. & órgano cimarrón, candelabra cactus & \\
\hline Stenocereus marginatus & (DC.) A. Berger \& Buxb. & órgano manso, organ pipe cactus & \\
\hline
\end{tabular}

are plans to create an UMA to facilitate this.

There are also dissenting opinions about the reserve; for example, the Flores brothers do not agree with the establishment of the biosphere reserve in the region. They complain that there have been prohibitions that do not make sense, which have adversely affected many residents. For example, in El Palmar, a very poor village, harvesting palm leaf (used in crafts) was prohibited. It is not fair, they say. If the biosphere doesn't let people use the natural resources, they should give alternatives, but they do not. The brothers say that they would agree with the existence of the biosphere reserve if there were justice and 


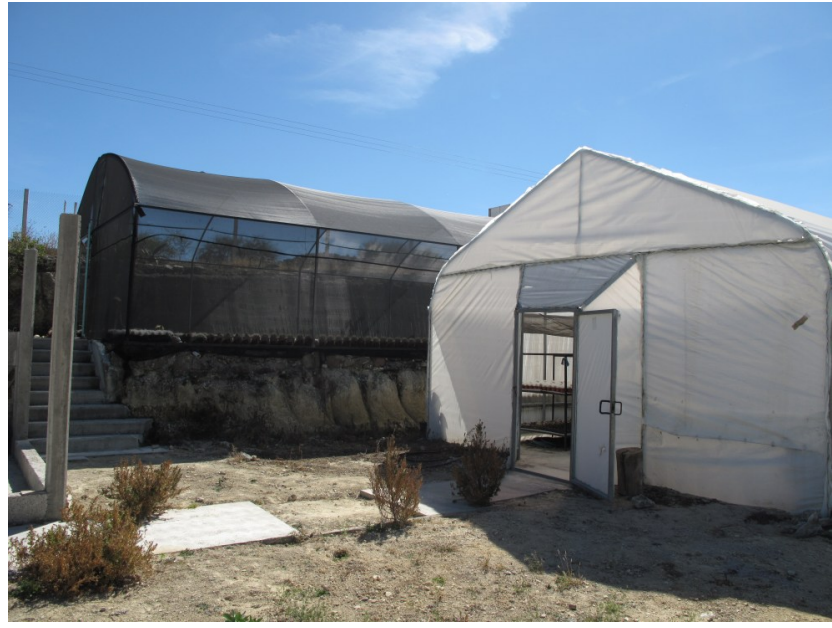

Figure 4. Florycactus Nursery.

fairness for all. Although the palm leaves could be harvested sustainably, it is difficult for local residents to obtain permits to do so (Coronel and Pulido 2011).

The sale of cacti generated the Flores brothers enough income to make a living, but, they stated, "the biosphere people got involved and then it was all over." Since the biosphere was established, the Flores brothers had to tell their customers that plants could no longer be removed, that they no longer had permission, and that they could be fined or imprisoned.

\section{Discussion}

The case study presented here suggests that the RBBM has resulted in a notable change in the use and management of cactus in the Metiztitlán region from uncontrolled extraction of wild plants to cultivation. These opinions expressed by local residents are corroborated by official data. This suggests that the nurseries and this ANP are quite successful from an ecological point of view and have brought direct and indirect benefits to their managers. Nevertheless, their success should be evaluated more thoroughly, since ANPs often do not improve the quality of life of local residents (Rodríguez and Bracamonte 2008).

The change in cactus conservation practices in Metztitlán has been a result of the efforts of the local population, resident groups, federal agencies, and other stakeholders. This study shows that although vertical decision making schemes are predominant in Mexican conservation, community based strategies are also incorporated, a trend that should be encouraged. The challenge is to take local stakeholders into account not only in execution phases, but also in analysis, planning and other stages, with the goal of having them operate autonomously. Community based conservation, co-management and decentralized decision making are some of the desirable aspects of current conservation strategies in socio-ecosystems (Berkes and Turner 2006; Campbell and Vainio 2003), which represent a significant challenge for RBBM.

Current knowledge of cactus management and propagation is the result of a combination of sources that include the empirical experience of local residents, in addition to the efforts of academic technicians and knowledge exchanges between peers. This knowledge acquisition has taken place over a few decades, according to the information gathered in this study, although it surely includes traditional knowledge acquired over centuries.

The nurseries provide a number of different benefits, including local jobs that enable nursery managers to make a living or at least to supplement their income, and have kept them from emigrating. The nurseries have provided an opportunity for personal growth, increased self-esteem, education, and other important benefits. However, the main limitation is the marketing issue. Although managers of the reserve considered doing a market study and forming a production chain to help them market the cactus, several of the nursery managers find that it is difficult to get enough buyers and they also find it difficult to maintain long term business relationships. This seems paradoxical considering that there is a large demand both domestically and internationally for these cacti, especially the largest ones.

The missing piece of the picture is better coordination among the efforts made by these stakeholders. In addition to receiving training on how to grow the cacti, they need training on how to apply for government support and improve their marketing capacity. NGOs could help create and strengthen these links, as developing local capacity is often part of the work they do. For example, the NGO Methodus Consultora has created new markets and improved links between local residents and potential customers for edible fungi in Oaxaca, Mexico (see Marshall, Schreckenberg, and Newton 2006). Although NGOs are not always a panacea, they are key actors who often catalyze local processes.

In addition to NGOs, lessons learned about NTFP show that in some contexts, middlemen can be 
key elements for commercial success, provided that there are better conditions for parity between producers and middlemen, and producers are more united (Marshall, Schreckenberg, and Newton 2006). Considering this, it is recommended that Metztitlán enter into the national ornamental plant market, perhaps with support from cactus cooperatives in the neighboring state of Puebla, which operate a successful business in the Tehuacán-Cuicatlán region. For the Metztitlán nursery managers to cooperate, they will have to overcome critical issues such as mutual distrust and competition for buyers. The solution to these problems is more sociological, which in this context is an inescapable factor for achieving success.

Another recommendation is that RBBM try to decentralize government support, so that the UMAs can seek support beyond the local municipal seat. This includes indigenous people who, although a minority, are the most needful of support. In addition, UMAs should not focus on cactus sales alone, which are intrinsically limited by slow growth, but should offer environmental education, ecotourism, and other activities enhanced by the presence of cacti.

\section{Declarations}

Permissions: None declared

Sources of funding: None declared

Conflicts of interest. None declared

\section{References Cited}

Anta Fonseca, A., J. Carabias, A. Díaz de León, C. Illsley, C. López, D. Robinson, E. Escamilla, F. Edouard, F. Ramírez, L. Merino, M. Chauvet, O. Ramírez, P. Álvarez, R. Obregón, S. Madrid, S. Purata, S. Ávila. 2008. Consecuencias de las Políticas Públicas en el Uso de los Ecosistemas y la Biodiversidad. In Capital Natural de México, vol. III: Politicas públicas y perspectivas de sustentabilidad, pp. 214 -218. CONABIO, México.

Berkes, F. 2003. Rethinking Community-Based Conservation. Conservation Biology 18:621-630.

Berkes, F. and N. J. Turner. 2006. Knowledge, Learning and the Evolution of Conservation Practice for Social-Ecological System Resilience. Human Ecology 34:479-478.

Boege, E. 2010. El Patrimonio Biocultural de los Pueblos Indígenas de México. Instituto Nacional de Antropología e Historia/ Comisión Nacional para el Desarrollo de los Pueblos Indígenas, México.
Bravo, H. 1978. Las Cactáceas de México, Vol. II. Universidad Nacional Autónoma de México, México.

Bowler, P. 2000. Historia Fontana de las Ciencias Ambientales. Fondo de Cultura Económica, México.

Campbell, L. M. and A. Vainio. 2003. Participatory Development and Community-Based Conservation: Opportunities Missed for Lessons Learned. Human Ecology 31:417-437.

CONANP. 2003. Programa de Manejo. Reserva de la Biosfera Barranca de Metztitlán. Comisión Nacional de Áreas Naturales Protegidas, México.

Coronel, M. and M. T. Pulido. 2011. ¿Es Posible Conservar y Usar a la Palma Brabea dulcis (Kunth) Mart. en el Estado de Hidalgo, México? In Manual de Herramientas Etnobotánicas Relativas a la Conservación y el Uso Sostenible de los Recursos Vegetales, edited by S. Lagos, O. L. Sanabria, P. Chacón, R. García, pp 103 -110. Red Latinoamericana de Botánica. Chile.

Cuevas-Cardona, C., A. P. Martínez- Falcón and O. A. Molina-González. 2008. Los Científicos en la Creación de las Areas Naturales Protegidas del Estado de Hidalgo. In Estudios Biológicos en las Areas Naturales del Estado de Hidalgo, edited by G. Pulido Flores, A. L. López Escamilla and M. T. Pulido Silva, pp. 7-17. Universidad Autónoma del Estado de Hidalgo, Pachuca, México.

Funtowicz, S. and B. de Marchi. 2003. Ciencia Posnormal, Complejidad Reflexiva y Sustentabilidad. In La Complejidad Ambiental, edited by E. Leff, pp. 5-84. Siglo XXI Editores, México.

Leff, E. 2005. Ecología y Capital. Siglo XXI Editores, México.

Marshall, E., K. Schreckenberg, and A. C. Newton. 2006. Comercialización de Productos Forestales no Maderables, Factores que Influyen en el Exito. Conclusiones del Estudio de México y Bolivia e Implicancias Políticas para los Tomadores de Decisiones. Centro Mundial de Vigilancia de la Conservación del PNUMA, Cambridge, UK.

PROFEPA. 2013. Sistema de Solicitudes de Información (INFOMEX). Exp PFPA/5.3/12c.6/000176_13. Folio 1613100017613. Procuraduría Federal de Protección al Ambiente, Delegación Hidalgo.

Pulido, M. T., M. S. González, P. Hersch, C. Illsley, C. 
López and F. Ramírez. 2010. Productos Forestales no Maderables: Consideraciones Sobre su Dimensión Económica. In Sistemas Biocognitivos Tradicionales: Paradigmas en la Conservación Biológica y el Fortalecimiento Cultural, edited by A. Moreno, M.T. Pulido, R. Mariaca, R. Valadéz, P. Mejía Correa and T.V. Gutiérrez, pp. 214-218. Universidad Autónoma del Estado de Hidalgo, Asociación Etnobiológica Mexicana y Sociedad Latinoamericana de Etnobiología. México.

Rodríguez, G. and A. Bracamonte. 2008. Pertinencia de las ANP Como Política de Conservación y Mejoramiento de la Calidad de Vida. Análisis de Percepción en la Reserva de la Biosfera del Alto Golfo de California y Delta del Río Colorado. Estudios Sociales 16:41-72.

Robbins, C. S. 2003. Comercio Espinoso. Comercio y Conservación de Cactos en el Desierto Chibuabuense. TRAFFIC North America WWF, Washington D.C.

Robles de Benito, R. 2009. Las Unidades de Manejo para la Conservación de Vida Silvestre y el Corredor Biológico Mesoamericano, México. CONABIO, México, D.F.
Toledo, V. M. 2002. Biodiversidad y Pueblos Indios en México y Centroamérica. Biodiversitas 43:1-8.

Turner, N. J. and F. Berkes. 2006. Developing Resource Management and Conservation. Human Ecology 34:375-478.

UNESCO. 2013. Biosphere Reserves - Learning Sites for Sustainable Development. Available at: http:/ / www.unesco.org/new/es/natural-sciences/ environment/ecological-sciences/biospherereserves/. Accessed on January 10, 2013.

Vázquez, M., T. Terrazas, S. Arias. 2007. Morphology and Anatomy of the Cephalocereus Columna-Trajani Cephalium: Why Tilting. Plant Systematics and Evolution 265:87-99.

\section{Biosketch}

María Teresa Pulido Silva has a PhD in Science. Her areas of research are ethnobotany, non-timber forest products, and traditional farming systems.

Consuelo Cuevas Cardona has a PhD in Science. His areas of research are the history of biology in Mexico and environmental history. 